\title{
Will the Canadian Courts make Meng Wanzhou's case their own Lotus?
} Sean D. Yates ${ }^{1 *}$

\author{
${ }^{1}$ The author is an English Barrister, General Counsel of China State Construction Engineering Corporation (Middle East) L.L.C. and \\ undertaking $\mathrm{PhD}$ research on new international commercial courts and their domestic relations
}

\begin{abstract}
DOI: $10.36348 /$ sijlcj.2021.v04i03.002
| Received: 22.02.2021 | Accepted: 05.03.2021 | Published: 10.03.2021

*Corresponding author: Sean D. Yates

Abstract

Customary law and the principles commonly used to establish or to challenge a State's jurisdiction over a particular matter. Territorial Principle, the Effects Doctrine, the Active Personality Principle, the Passive Personality Principle, the Protective Principle, and the Universality Principle. Application of the law to the facts of Meng Wangzhou's case to see whether the case itself constitutes an abuse of process if the US has acted illegally under international law in exercising jurisdiction in the case through the alleged connection of the US banking system. How public international law is regulated by the international community and what States can do if a State imposes unilateral sanctions or exercises jurisdiction illegally. Should Canada be complicit in helping the US when the US exercise of jurisdiction is illegal under international law and further questions the approach the US has taken in bringing this case.
\end{abstract}

Keywords: Lotus, Customary law, Meng Wangzhou's.

Copyright (C) 2021 The Author(s): This is an open-access article distributed under the terms of the Creative Commons Attribution 4.0 International License (CC BY-NC 4.0) which permits unrestricted use, distribution, and reproduction in any medium for non-commercial use provided the original author and source are credited.

\section{INTRODUCTION}

When a group of law students in a lecture were asked which country could claim jurisdiction over a criminal act initiated in Belgium and consummated in France, one student volunteered 'the United States!'[1] The response underlies how the long arm of the United States of America ('US') and the perceived frequent imposition of its laws on individuals, companies and other States have entered the collective psyche and even become a source of humour. Any legal basis for this exercise of jurisdiction is less understood, as much by lawyers as laypeople, not least because the relevant law appears unclear and inconsistent in its application. Public international law on jurisdiction is typically concerned with preventing a clash of sovereignties; it guides States on what they should not do, by delimiting jurisdiction; [2] it deals with concurrent jurisdiction issues, where two or more States claim jurisdiction over the same matter, but also with cases where a single State claims jurisdiction outside of its borders.

${ }^{1}$ Ryngaert, C. (2015). Jurisdiction in international law, OUP Oxford.

${ }^{2}$ However, in human rights law, it usually does the opposite, requiring States to adopt certain standards within their jurisdiction. See Article 1 of European Convention on Human Rights.
This is the third article from the author which looks at the case of Huawei's CFO, Meng Wanzhou, who currently faces extradition from Canada to the US to face charges[3] that in August 2013 she misled HSBC Bank ('HSBC') concerning Huawei's relationship with a company operating in Iran named Skycom Tech. HSBC extended a financial facility to Huawei which it says it might not have done had those representations not been made and the actual relationship with Skycom been disclosed. HSBC is said to have been put at risk of fines and penalties and reputational damage because of the US sanctions against Iran. Specifically, Meng is said to have shown a Powerpoint presentation containing misleading information to an HSBC employee in a cafe in Hong Kong. HSBC subsequently routed funds through the US banking system to Huawei. This use of the US banking system by HSBC is the connection the US uses to assert jurisdiction and to charge Meng with the alleged offences.
${ }^{3}$ Bank fraud in violation of 18 U.S.C. $\S 1344$, wire fraud in violation of 18 U.S.C. $\S 1343$, and conspiracy to commit those offences in violation of 18 U.S.C. $\$ 1349$. 
Sean D. Yates., Sch Int J Law Crime Justice, Mar, 2021; 4(3): 136-143

This paper begins with an analysis of the 1927 Lotus case, notable in part for its setting down of concepts of prescriptive and enforcement jurisdiction in the field of public international law, but equally for the departure subsequently taken from its approach by the international community. This departure has created a significant body of law which has evolved into the customary law that forms the basis of how States are expected to deal with each other in their exercise of international jurisdiction. The second part provides an overview of the principles commonly used to establish or to challenge a State's jurisdiction over a particular matter and whether any of them can be brought to bear on Meng's case. The third section considers the application of the law to the facts of Meng's case to consider whether the case constitutes an abuse of process. The paper concludes by looking at how public international law is regulated by the international community.

\section{The Lotus Case v Customary Law}

In the 1927 Lotus case,[4] the Permanent Court of International Justice distinguished between prescriptive jurisdiction, that is the right to make laws, and enforcement jurisdiction, the right to enforce those laws. The court held that unless there was a rule or law to the contrary, a State could make laws relating to people or events outside of its physical territory, but that again, absent a contrary rule or law, a State could not enforce those laws in another State's territory. Under Lotus, States are therefore relatively free to create laws and rules with an extraterritorial effect but restricted when it comes to their extraterritorial enforcement.

The Lotus case was however criticised, and in 1970 the ICJ pointed to the existence of international norms which limited the apparent freedom of States to exercise their jurisdiction over other sovereign States. It held there was an obligation on every State '...to exercise moderation and restraint as to the extent of the jurisdiction assumed by the courts in cases having a foreign element, and to avoid undue encroachment on a jurisdiction more properly appertaining to, or more appropriately exercisable by, another State.' [5]

Further, custom and practice have developed in the way States approach issues of jurisdiction that clearly run contrary to the Lotus position.[6] As

${ }^{4}$ SS Lotus, PCIJ Reports, Series A, No 10 (1927).
${ }^{5}$ Barcelona Traction, Light and Power Co. Ltd.
(Belgium v Spain), [1970] ICJ Reports 105SS Lotus,
PCIJ Reports, Series A, No 10 (1927).
${ }^{6}$ See ICJ, Arrest Warrant (Democratic Republic of Congo
v Belgium), ICJ Rep 3 (2002), "It has often been argued,
not without reason, that the 'Lotus' test is too liberal and
that, given the growing complexity of contemporary
international intercourse, a more restrictive approach
Ryngaert highlights, however, as it is the only judgement of an international court relating to jurisdiction, Lotus is still referred to.[7]

Customary international law 'results from a general and consistent practise of States followed out of a sense of international legal right or obligation' [8] and requires 'a settled practice' and 'a belief that this practice is rendered obligatory by the existence of a rule of law requiring it.' [9] Customary international law is considered to reverse the Lotus position on prescriptive jurisdiction, prohibiting it in the absence of any permissive rule to the contrary. In the 2002 Arrest Warrant case, the ICJ confirmed this position: 'Under the law as classically formulated, a State normally has jurisdiction over an offence committed abroad only if the offender, or at the very least the victim, has the nationality of that State or if the crime threatens its internal or external security. Ordinarily, States are without jurisdiction over crimes committed abroad as between foreigners.'

The Customary law definition is subject to change and comes with the need in any given case to ascertain the current position according to custom and practice. It must be argued afresh, each time it is relied upon. However, established principles provide pointers to assist in this exercise.

\section{Principles of International Jurisdiction}

Six principles have developed under customary international law to govern the circumstances where a State can exercise jurisdiction, the 'territorial' and 'effects' principle or doctrine, the 'active personality' and 'passive personality' principles, the 'protective principle' and the 'universality principle'. Each of these will be considered to illustrate the circumstances where they are typically invoked. Although only the effects doctrine is relied upon by the US in Meng's case, a contextual review provides a broader perspective from which to consider the appropriateness of its application.

Importantly, there is no priority as between these principles so far as international law is concerned. [10] Those relating to extraterritorial jurisdiction are not

should be adopted today." van den Wyngaert, § 51, dissenting. Emmenegger, S. (2016). "Extraterritorial Economic Sanctions and Their Foundation in International Law." Ariz. J. Int'l \& Comp. L. 33: 631.

${ }^{7}$ Ryngaert, C. (2015). Jurisdiction in international law, OUP Oxford.

${ }^{8}$ American Law Institute's Restatement (Fourth) of the Foreign Relations Law of the United States (2018) § 401 comment a.

${ }^{9}$ North Sea Continental Shelf (F.R.G. v. Den., F.R.G. v. Neth.), 1969 I.C.J. 3, 44 (Feb. 20).

${ }^{10}$ Ryngaert, C. (2015). Jurisdiction in international law, 
Sean D. Yates., Sch Int J Law Crime Justice, Mar, 2021; 4(3): 136-143

therefore secondary to the territorial principle. Two further factors should also be emphasised; first, these principles can and typically do operate concurrently. A State seeking to exercise jurisdiction will typically rely on more than one principle to support its position. Secondly, concurrency of application also operates to give multiple States claims to jurisdiction over the same event.

Finally, in a reversal from the position appearing in its 1987 predecessor, the 2018 Restatement (Fourth) of US Foreign Relations Law ('2018 Restatement') confirms that there is no reasonableness principle to be applied on a case-by-case basis when, under US law or in international customary law, courts determine an issue of extra-territoriality. However, as Dodge highlights, a reasonableness principle is still found in the requirement of a 'genuine connection' between the regulated subject and the State seeking to regulate[11] and under US domestic law, a principle of reasonableness is found in two rules of statutory interpretation: the presumption against extraterritoriality and the principle of reasonableness in interpretation.[12]

\section{The Territorial Principle and Effects Doctrine}

Customary law relating to international jurisdiction recognises territoriality as the basic principle allowing a State to exercise jurisdiction within its geographic borders.[13] Broadening this scope are (i) subjective territorialism where a crime starts in the State but is completed outside, and (ii) objective territorialism where 'any essential constituent element' of the crime is committed within the State, even though other elements are committed outside.[14] Objective territorialism is also known as the effects principle or doctrine and is the basis upon which the US relies in Meng's case to provide the jurisdictional nexus. Unlike subjective territorialism, there is no requirement for a constituent element of the crime to have taken place within the territory.[15] As a principle, it is contentious and is rightly stated to be extraterritorial rather than

OUP Oxford.

11 Dodge, W. S. (2018). "Reasonableness in the Restatement (Fourth) of Foreign Relations Law." Willamette L. Rev. 55: 521.

${ }^{12}$ Ibid.

${ }^{13}$ Koskenniemi, M. (2012). Brownlie's Principles of Public International Law. By James Crawford AC, SC, FBA, Oxford University Press.

'The starting-point in this part of the law is the presumption that jurisdiction (in all its forms) is territorial, and may not be exercised extraterritorially without some specific basis in international law.'

${ }^{14}$ Ibid.

${ }^{15}$ American Law Institute's Restatement (Fourth) of the Foreign Relations Law of the United States (2018) § 409 comment a. territorial in nature. The 2006 International Law Commission Report ('ILC 2006 Report') states that the effects doctrine: 'may be understood as referring to jurisdiction asserted with regard to the conduct of a foreign national occurring outside the territory of a state which has a substantial effect within that territory. This basis, while closely related to the objective territoriality principle, does not require that an element of the conduct take place in the territory of the regulating State.'[16]

The ILC 2006 Report indicates the application of the effects doctrine in criminal law has been 'controversial' [ 17 ] and Norton pointed to its divisiveness in 1977, 'This exposition of the so-called "effects" doctrine of territorial jurisdiction has developed considerable controversy in international legal circles, and has been the subject of heated discussion within the Community.'[18]

Parrish identifies US Ninth Circuit, DC Circuit, and Supreme Court decisions that created an effects test which became characterised as territorial, thereby eluding the requirement to be satisfied that Congress intended the law in question to have extraterritorial effect.[ 19 ] The 2018 Restatement records that effects-based jurisdiction 'has become more accepted over time, though the extent to which it can be invoked remains controversial.'[20]

The requirement for a "substantial" effect found in the ILC 2006 Report is also found in the 2018 Restatement.[21] Crawford summarises in Brownlie's Principles of Public International Law that ' $[\mathrm{t}]$ here should be a real and not colourable connection between the subject matter and the source of the jurisdiction.'[22] In Hartford Fire Insurance Co. v. California,[23] a case involving US anti-trust law, the court held the law to apply to foreign conduct that "was

\footnotetext{
${ }^{16}$ International Law Commission, Report to the General Assembly, Annex V, U.N. Doc. A/61/10 $\square$ p. 231

${ }^{17}$ Ibid p232.

${ }^{18}$ Norton, J. J. (2020). "The European Court of Justice Judgement in United Brands: Extraterritorial Jurisdiction and Abuse of Dominant Position." Denver Journal of International Law \& Policy 8(2): 3.

${ }^{19}$ Parrish, A. L. (2011). "Evading Legislative Jurisdiction." Notre Dame L. Rev. 87: 1673.

${ }^{20}$ American Law Institute's Restatement (Fourth) of the Foreign Relations Law of the United States (2018) § 409 reporters' note 1 .

${ }^{21}$ American Law Institute's Restatement (Fourth) of the Foreign Relations Law of the United States (2018) § 402 reporters' note 6 .

${ }^{22}$ Crawford, J. (2019). Brownlie's Principles of Public International Law, Oxford University Press, USA.

${ }^{23}$ Hartford Fire Insurance Co. v. California 509 U.S. 764, 796 (1993).
} 
Sean D. Yates., Sch Int J Law Crime Justice, Mar, 2021; 4(3): 136-143

meant to produce and did, in fact, produce some substantial effect in the US.' Three elements, therefore, present as requirements to satisfy the effects doctrine causation, intention, and a substantial effect. This is in keeping with Ryngaert's summary that the activity must have a 'substantial, direct, and foreseeable effect upon or in the territory.' [24]

\section{The Active Personality Principle}

Under this principle, a State can assert jurisdiction over one of its citizens for a crime committed abroad. Use of this principle is usually tempered by additional requirements such as dual criminality, requiring that the crime also constitutes an offence in the State where it took place. This might be utilised by States holding a policy of non-extradition of its own citizens who are accused of committing a crime abroad. Impunity is avoided by the home State's prosecution. This is generally considered an uncontroversial principle. As Meng was neither a US citizen nor resident in the US at the time of the alleged offence, this principle cannot apply in her case. It is however an example of a State being able to exercise jurisdiction beyond its borders.

\section{The Passive Personality Principle}

The passive personality principle has been described as having been 'more strongly contested than any other type of competence'[25] and as being 'quite likely, the most aggressive basis for extraterritorial jurisdiction.'[26] The principle is applied according to the nationality of the victim of the offence and involves the victim's State asserting jurisdiction abroad, otherwise straightforward territorial jurisdiction would apply. As with the active personality principle, dual criminality status of the offence is typically required.

The Restatement (Third) of US Foreign Relations Law (1987) ('1987 Restatement') highlighted that there was no general acceptance of the passive personality principle for 'ordinary torts or crimes' but that it was 'increasingly accepted as applied to terrorist and other organized attacks on a State's nationals by reason of their nationality, or to assassination of a state's diplomatic representatives or other officials.'[27] The 2018 Restatement reiterated it as the basis for prescribing terrorist offences and attacks on government officials.[28]

\footnotetext{
${ }^{24}$ Ryngaert, C. (2015). Jurisdiction in International Law, OUP Oxford.

${ }^{25}$ Harvard Research on International Law, "Draft Convention on Jurisdiction with Respect to Crime," (1935) 29 AJIL 439 at 579.

${ }^{26}$ Ryngaert, C. (2015). Jurisdiction in International Law, OUP Oxford.

${ }^{27}$ Restatement (Third) of US Foreign Relations Law (1987), § 402, cmt g.

${ }^{28}$ Restatement (Fourth) of the Foreign Relations Law of the
}

The uncertainty inherent in the application of the passive personality jurisdiction has led to calls for a 'uniform regime' and 'international streamlining and consolidation of the...restrictive conditions' attaching to its application.[29] Blakesley says coherence in grounds for jurisdiction is particularly needed in the area of extradition.[30] This principle should not have any effect in Meng's case for two reasons. First, because HSBC, against which the fraud is said to have been committed is not a US company. Secondly, even if the fraud is alleged to have been perpetrated against US correspondent banks, the nature of the alleged offence, cannot be equated with acts of terrorism.

\section{The Protective Principle}

The protective principle is to be invoked where national security is at risk, and so its use is exceptional. The ICL 2006 Report states the protective principle:

'may be understood as referring to the jurisdiction that a State may exercise with respect to persons, property or acts abroad which constitute a threat to the fundamental national interests of a State, such as a foreign threat to the national security of a State.' [31]

In the case of secondary boycotts, which apply to foreign entities and persons dealing with the boycotted State, the protective principle acts to universalise a boycott imposed by the sanctioning State. The effect is to dictate another State's foreign policy and was considered illegal when the US sought to impose its policy on the European Community in its dealings with the former USSR.[32] It has been suggested that invoking the protective principle to justify a secondary boycott might only be justified in times of war, where there is a direct threat to national security, or where the primary boycott addresses a threat to international security.

Given the principle is to be invoked where national security is at risk, it is difficult to see how standard business dealings can be linked and jurisdiction invoked. Iran's nuclear ambitions may be seen as a threat to US security interests. Still, it does not follow that all business transactions relating to Iran contribute to this threat and therefore justify prosecution under the secondary sanctions regime,

United States (2018) $§ 411$.

${ }^{29}$ Ryngaert, C. (2015). Jurisdiction in International Law, OUP Oxford.

${ }^{30}$ Blakesley, C. L. (1999). "Extraterritorial Jurisdiction." International Criminal Law 2: 85-152.

${ }^{31}$ International Law Commission, Report to the General Assembly, Annex V, U.N. Doc. A/61/10 p. 231

${ }^{32}$ European Community: Note and Comments on the Amendments of 22 June 1982 to the Export Administration Act, Presented to the United States Department of State on 12 August 1982, (1982) 21 ILM at 895. 
Sean D. Yates., Sch Int J Law Crime Justice, Mar, 2021; 4(3): 136-143

through jurisdiction obtained under the protective principle.[33]

\section{Universality Principle}

The broadest principle, which does not require any nexus with the regulating State, is the universality principle and must be relied upon when none of the other principles can be established. Its utility is against certain crimes where it is considered that any State may prosecute regardless as to where the crimes took place or the nationality of the perpetrator or the victim and might include such crimes as human trafficking, counterfeiting, sexual offences, corruption and distribution of narcotics or pornography.[34] There is however no settled position as to which crimes customary international law should treat as being subject to universal jurisdiction:

'by idiosyncratically defining universal crimes however it likes, a State theoretically could declare its entire body of national law applicable inside the territory of every other State in the world.'[35]

The 2018 Restatement identifies the principle as being reserved for the most serious of offences:

'Because it departs from the more typical requirement of a specific connection between the state exercising jurisdiction and the person or conduct being regulated, universal jurisdiction is limited to the most serious offenses about which a consensus has arisen for the existence of universal jurisdiction.' [36]

The ILC 2006 Report characterises the use of the universality principle as being exercised 'with respect to certain crimes under international law in the interest of the international community.' [37]

From this, it is apparent that the more serious the offence, the greater the extraterritorial jurisdiction the international community is prepared to allow. However, such an approach is open to abuse by a State which, for political or economic reasons, seeks to claim jurisdiction by using the broadest principles where they are not typically applied. For example, exaggeration of the seriousness of the crime, or its effects may be used to extend the extraterritorial jurisdiction, but at the cost of undermining customary international law norms. The

\footnotetext{
${ }^{33}$ Emmenegger, S. (2016). "Extraterritorial Economic Sanctions and Their Foundation in International Law." Ariz. J. Int'l \& Comp. L. 33: 631.

${ }^{34}$ Ryngaert, C. (2015). Jurisdiction in International Law, OUP Oxford.

${ }^{35}$ AJ Colangelo, "Universal Jurisdiction as an International False Conflict Of Laws" (2008) 30 Mich J Int'l L 881, 902.

${ }^{36}$ Restatement (Fourth) of the Foreign Relations Law of the United States (2018) § 413 reporters' note 1.

${ }^{37}$ International Law Commission, Report to the General Assembly, Annex V, U.N. Doc. A/61/10 $\square$ p. 231
}

danger is increased because, in those areas where jurisdiction approaches universal status, such as international terrorism, there is little precedent of international challenge - most States accept the need to take action against such crimes - so that its circumscription and the limits to its application are not well defined.

It should be noted that some crimes are also subject to international conventions, which may have their own jurisdiction clauses. An example is the United nations Torture Convention.[38] Such conventions will, though, only bind signatory States. By contrast, there is no settled position as to which crimes customary international law should treat as being subject to universal jurisdiction, and there are no conventions relating to extraterritorial jurisdiction and the breach of sanctions.

\section{Meng's Case \\ Causation, Substantial Effect, Intention}

The absence of intention undermines the substantial effect requirement, as without intention the link between the person and any effect cannot be satisfied. Wilson said of attempts to create a nexus with the US-based solely on correspondent bank accounts having been used as being insufficient to meet the threshold of conduct having occurred 'wholly or in substantial part' in the territory for the purposes of the 1987 Restatement.[ 39 ] Emmenegger has likewise challenged the use of correspondent bank facilities amounting to a nexus.[40]

In Meng's case, it was not foreseeable that funds would necessarily be routed through the US clearing system. This was the choice of HSBC which could also have availed of the Hong Kong Clearing House Automated Transfer System ('CHATS') which would have resulted in the funds clearing in Hong Kong. A US correspondent bank and the claimed US nexus could have been avoided altogether. Further, even where the use of a correspondent bank was sufficient to establish territorial jurisdiction, that this could further encompass the bank's customer, who lacks intention or even awareness that funds would be processed in this way is far-fetched. A further sense in which the effects doctrine must fail in Meng's case is the unsatisfied requirement that the effects be substantial and direct. The transaction under consideration was neither, being transitory and passing

\footnotetext{
${ }^{38}$ See Article 5(2).

${ }^{39}$ Wilson, N. N. (2013). "Pushing the limits of jurisdiction over foreign actors under the Foreign Corrupt Practices Act." Wash. UL Rev. 91: 1063.

${ }^{40}$ Emmenegger, S. (2016). "Extraterritorial Economic Sanctions and Their Foundation in International Law." Ariz. J. Int'l \& Comp. L. 33: 631.
} 
Sean D. Yates., Sch Int J Law Crime Justice, Mar, 2021; 4(3): 136-143

indirectly between two foreign banks using the US correspondent banks as intermediaries.

To establish causation and bring Meng's case under its jurisdiction, the US combines the facts of two offences. There are two separate sets of facts, not linked because of a break in causation - HSBC opting to use the US banking system. The first set of facts involves the allegation that Meng misled HSBC regarding Huawei's relationship with SkyCom, thereby obtaining a facility that may not otherwise have been available. The US has no legitimate interest over this first set of facts, which took place in Hong Kong. The second set of facts is that HSBC used a US clearing bank to route funds, in breach of US sanctions law because of the Iran connection. Assuming, which is not certain, the US has jurisdiction over this second set of facts, they did not involve Meng and nor did she have any control over them. They were part of HSBC's internal transaction processes, and as such, do not give the US any jurisdiction over HSBC's customer.

In theory, if the US is correct about the second offence-the transfer using correspondent banks, it does not need to rely on fraudulent allegations against HSBC. If the mere transfer of funds through the US banking system is enough, and attaches to the customer as well as the bank, without intention, foreseeability or a substantive effect being established, it does not need to rely on representations made to HSBC. Yet, in such a case, the prosecution would look malicious, against an innocent customer unaware of having done anything wrong. By attributing the otherwise unconnected meeting with HSBC and alleging fraudulent conduct, the US projects wrongdoing onto Meng and creates the impression of a series of connected events. In neither fact pattern could the US exercise jurisdiction against Meng or Huawei. Accordingly, by sleight of hand, it seeks to blend the two fact patterns, to arrive at a jurisdictional position it could not have reached in either pattern alone.

The charges brought may reveal this to be the case - bank fraud and wire fraud. Bank fraud relates to fact pattern one, where the US has no jurisdiction, and wire fraud to fact pattern two, which does not involve Meng. The additional conspiracy charge attempts to connect them, even though conspiracy to commit an offence cannot operate in this way - conspiracy to commit an offence cannot succeed where the standalone offence itself is incapable of succeeding. This is also why the US seeks to transfer the alleged fraud against HSBC to a fraud against the US corresponding banks. Without this link, the requirements of an effect being 'direct' and 'foreseeable' cannot be satisfied. There must be an intention to defraud the corresponding banks for any substantial effect to be direct and foreseeable.
The problems relating to causation, substantial effect, and intention in Meng's case can all be traced back to this attempt artificially to blend the two fact patterns into one, like twisting strands into a rope, hoping they will hold. This leads to consideration of perhaps the most disturbing aspect of the case, the idea that motivation for the prosecution does not emanate from any suspected crime at all, which will be discussed in the next section.

\section{Regulation of Public International Law}

The system of public international law is held in place by States' mutual respect for each others' sovereignty or comity. What legal options are available to the international community when self-regulation proves ineffective? Two are commonly identified, triggered according to the nature of the transgression. On a large scale, sanctions unilaterally imposed by one State against another that are deemed to be unlawful under international law may be met by blocking legislation. Unlawful jurisdiction exercised by a State over individuals or corporations may be met with a refusal by a State to extradite persons to the requesting State. Both of these will be briefly considered.

\section{Sanctions}

The US Foreign Corrupt Practices Act ('FCPA'), criminalising the bribing of foreign officials, includes both nationality and territorial principles in its jurisdiction. It applies to US persons, even where there is no nexus between the act of bribery and the US[41] and to companies registered or with their principal place of business in the US.[42] However, the territorial scope of the FCPA significantly extends this to all companies issuing stock on US securities exchanges and to any person acting within US territory if they cause, whether directly or through agents, any act which furthers the corrupt payment to take place within the US.[43] This wording has been interpreted to allow prosecutions against non-US citizens outside of the US when the only connection with the US was routing payments through US bank accounts or even sending an email to a US company. In US v Reza Zarrab, [44] for example, it was held that the use of a corresponding bank situated in the US amounted to the export of services from the US, which gave rise to territorial jurisdiction. This is despite the defendant's complaint of 'prosecutorial overreach of the first order' in circumstances where he:

'stands accused of violating U.S. law for agreeing with foreign persons in foreign countries to direct foreign banks to send funds transfers from foreign companies to

\footnotetext{
${ }^{41}$ FCPA $78 d d-1(\mathrm{~g}), 78 \mathrm{dd}-2(\mathrm{i})$

${ }^{42}$ FCPA 78dd-2(h)(1)

${ }^{43}$ FCPA 78dd-1(a), 78dd-2, 78dd-3

${ }^{44}$ US v Reza Zarrab United States, District Court Decision \& Order, 17 October 2016, 15 Cr. 867
} 
Sean D. Yates., Sch Int J Law Crime Justice, Mar, 2021; 4(3): 136-143

other foreign banks for foreign companies.'[45]

The reasoning in the Reza case, creating the required nexus through the corresponding bank has been challenged[46] and what constitutes 'substantial' for the effects doctrine remains unclear.[47]

In United States $v$ Technip SA,[48] bribes had been paid by a company to Nigerian officials through UK and Japanese intermediaries and US banks had been used to route payments. Also, the same company had American Depository Receipts listed on the New York Stock Exchange. This company ultimately settled with the DOJ and SEC, paying US\$338 million, reflecting criminal penalties and profit.

State sanctions may be primary, prohibiting economic dealings with the target State by the sanctioning and its nationals. Extraterritorial or secondary sanctions operate on foreign persons for actions they take outside the sanctioning State.[49] A consequence of extraterritorial jurisdiction being exercised through secondary sanctions has been the use of countervailing or 'blocking' legislation from States seeking to neutralise the effect of what is seen as overreaching jurisdiction. An example is EU Council Regulation 2271/96 of 22 November 1996 which recorded that:

'A third country has enacted certain laws, regulations, and other legislative instruments which purport to regulate activities of natural and legal persons under the jurisdiction of the Member State and that[w] here as by their extraterritorial application such laws, regulations and other legislative instruments violate international law...'[50]

The EU Council Regulation applied to sanctions aimed at Cuba and Iran, and required EU persons and businesses not to comply with the sanctions or if they were forced to comply, providing for reimbursement of the costs associated with such compliance.

\footnotetext{
${ }^{45}$ https://www.lit-

wc.shearman.com/siteFiles/14416/United\%20States\%20v. \%20Zarrab,\%20Case\%20No.\%20115-cr00867\%20(S.D.N.Y.\%20October\%2017,\%202016).pdf

${ }^{46}$ Emmenegger, S. (2016). "Extraterritorial Economic Sanctions and Their Foundation in International Law." Ariz. J. Int'l \& Comp. L. 33: 631.

${ }^{47}$ Ibid.

${ }^{48}$ (Plea Agreement) (SD Tex, No 4:10-CR-00439, 28 June 2010),

${ }^{49}$ Rathbone, M. (2012). "Sanctions, Sanctions Everywhere: Forging a Path Through Complex Transnational Sanctions Laws." Geo. J. Int'1 L. 44: 1055.

${ }^{50}$ EU Council Regulation (EC) No 2271/96 of 22
} November 1996.
Specific to Meng's case, the extraterritorial aspect of legislation giving rise to the US sanctions against Iran, the US Comprehensive Iran Sanctions, Accountability, and Divestment Act of 2010 ("CISADA")[51] was not accepted by China, Russia or India even though the EU acquiesced, having similar sanctions of its own.[52] In the Harvard Law Review's Developments in the Law 2011 series on Extraterritoriality, it was said of CISADA that it is at least as provocative as Helms-Burton and the ILSA and of equally dubious permissibility under international law.'[53] In Meng's case, however, the US rather relies on the effects doctrine, claiming a nexus of the use of US correspondent banks, rather than the protective principle.

\section{Refusal to Extradite}

State resistance to extradition requests against individuals, outside of high profile cases, is in many ways more difficult to deploy consistently, as the facts of each case render the application of general principles a rather blunt device. The seriousness of allegations, the requesting and requested States' identities and settlements based on financial penalty alternatives reduce the predictability of outcome and the ability to track the consistent application of core principles. Extradition denial is, however, a powerful check on abuse of process and breach of international law, and a positive obligation on States where another State acts illegally.

In Meng's case, the tenuous nexus of the bank clearing system, the absence of substantial effect, causation and intention stand in sharp contrast to the disproportionate efforts to further her prosecution, which include the lengthy and expensive extradition process. The aide to the interpretation of the relevant customary international law involves discussion of terrorism, genocide, and human trafficking when the subject case involves an unexceptional business banking transaction. It is unlikely to be disclosed how the investigation in Meng's case began. Who decided to look into the alleged criminal conduct and why? How did the Hong Kong meeting arouse suspicion? What were the substantial effects on the US banking system that triggered review? Or was this, as it appears, a targeted attack against Huawei and Chinese tech? The investigation process appears to have been reversed. Instead of reviewing facts to see if a crime has been committed, the exercise appears to have been to create a crime from whatever facts were available. The case, therefore, appears vexatious.

\footnotetext{
${ }^{51} 50$ USCA $\S 1701$

${ }^{52}$ EU Council Decision of 26 July 2010.

${ }^{53}$ Parrish, A. L. (2011). "Developments in the Law Extraterritoriality." Harvard Law Review 124.
} 
Sean D. Yates., Sch Int J Law Crime Justice, Mar, 2021; 4(3): 136-143

Any move away from a connection-based assessment of jurisdiction towards an interest-based assessment necessarily redirects to a more subjective and ultimately politicised analysis, and further away from the law. Should criminal prosecution be abused as a tool to gain commercial advantage over another State? Prosecution of unworthy cases has its counterpart in the failure to prosecute serious cases because the perpetrator or the outcome are considered favourable albeit illegal, which is equally undesirable. The politicisation of whether to prosecute undermines the international rule of law and the legitimacy of the enforcing State. It further encourages other States to behave in a like manner, particularly when the State is dominant and influential.

The Canadian courts can act in cases where the breach of customary international law by a requesting State would amount to an abuse of process if Canadian courts were to confirm or act in a way that accepted the underlying illegality. In $R \quad v$ O'Connor[54] three members of the Supreme Court[55] observed that:

'The panoply of diverse and sometimes unforeseeable circumstances in which a prosecution is conducted in such a manner as to connote unfairness or vexatiousness of such a degree that it contravenes fundamental notions of justice and thus undermines the integrity of the judicial process.'[56]

The approach was confirmed in the Nevsun Resources case[57] by Abella J. who said:

'Our courts determine questions dealing with the enforcement of foreign laws according to ordinary private international law principles which generally call for deference, but allow for judicial discretion to decline to enforce foreign laws where such laws are contrary to public policy, including respect for public international law.'[58]

Arguably the Canadian courts have not only the ability but also an obligation to stay cases involving illegality. They should do this because all States mutually depend on each other to do so. Public International law is upheld by States acting within accepted norms, but equally by States taking action against transgressing States, whether those States be considered friendly or otherwise. The further reason why the Canadian court must act is because any failure to do so sets a precedent as much as their positive sanction. The message conveyed by inaction is that prosecution of the type seen in Meng's case is

\footnotetext{
${ }^{54}$ R. v. O'Connor, 1995 CanLII 51 (SCC), [1995] 4 SCR 411

${ }^{55}$ La Forest, L'Heureux-Dubé and Gonthier JJ

${ }^{56}$ R. v. O'Connor, 1995 CanLII 51 (SCC), [1995] 4 SCR 411 para 73.

${ }^{57}$ Nevsun Resources Ltd. v. Araya, 2020 SCC 5.

${ }^{58}$ Nevsun Resources Ltd. v. Araya, 2020 SCC 5, para 45.
}

acceptable. This means every CFO, of every corporation transacting in US dollars through the US banking system, potentially falls under US jurisdiction for entirely foreign activities, should the US authorities consider it beneficial for them to prosecute.

\section{CONCLUSION}

This paper has considered some aspects of public international law jurisdiction, to put into perspective and provide a baseline for when extraterritorial jurisdiction is usually exercised. It has also considered why self-regulation of and between States is fundamental to customary international law's creation and appropriately restrained development and to preserve comity. The international rule of law requires consistent application of customary international legal principles and cannot countenance politicised prosecution or indeed its opposite.

Meng's case is, it is suggested, important not only in itself but because of its likely influence over future cases. Each of the legal issues in Meng's defence has been made exhaustively, by teams of leading legal advisers and supported by academic experts in their respective fields.[59] Seldom does any party to proceedings, let alone a defendant have such legal resources at its disposal. All of them say the US has acted illegally in bringing this case. If the Canadian courts allow her extradition, there are no legal points left to be made, and the bar is permanently lowered to allow this type of prosecution to proceed. The question is whether the Canadian courts wish to create their own Lotus case, remarkable as a point of departure in the future as a result of getting it wrong.

\footnotetext{
${ }^{59}$ Prof. William S. Dodge, Martin Luther King, Jr. Professor of Law and John D. Ayer Chair in Business Law at the University of California; Prof. Dr. Cedric Ryngaert, Professor of Public International Law at Utrecht University; Regis Bismuth, Professor of International Law at Sciences Po Law School (Paris); Philippe Sands QC, Professor of Public International Law at University College, London; Nicolas Angelet, professor of public international law at the Universite Libre de Bruxelles, Belgium; Todd F. Buchwald former head of United States Department of State Office of Global Criminal Justice; John F. Simonson, former Director of the Office of Complex Financial Institutions at the Federal Deposit Insurance Corporation regulations, expectations, policies and practices.
} 